\title{
Quenchofluorimetric Determination of Cobalt (II) At Ultra trace Levels Using Bathophenanthrolinedisulphonate
}

\author{
Prof. B. K. Pal ${ }^{1}$, Dr. K. Anand Singh ${ }^{2}$ \\ ${ }^{I}$ (Analytical Chemistry Research Laboratory, Jadavpur University, Kolkata, India) \\ ${ }^{2}$ (Department of Chemistry, Moirang College, Manipur, India)
}

\begin{abstract}
A very simple, rapid, highly selective and ultrasensitive fluorimetric method for the determination of Cobalt (II) has been developed. The method is based on the instantaneous quenching action of Cobalt(II) on the native fluorescence of Bathophenanthrolinedisulphonate (4,7-diphenyl-1,10-phenanthroline disulphonate) having excitation and emission wavelength maxima at 288nm and $444.8 \mathrm{~nm}$ respectively in the optimum $\mathrm{pH}$ range of 4.0-4.7.The fluorescence intensity versus Cobalt (II) concentration calibration graph was rectilinear for a total range of 0.001-1.0ppm Cobalt (II).The standard deviation and relative standard deviation for 11 replicate determinations of 50ppb Cobalt (II) were found to be 0.435 and $0.868 \%$ respectively.
\end{abstract}

Keywords: Bathophenanthrolinedisulphonate, Cobalt (II), Environmental samples, Quenchofluorimetry, Toxicity.

\section{Introduction}

Cobalt is relatively rare element, comprising only $0.001 \%$ of the earth's crust. Cobalt is necessary for vitamin $\mathrm{B}_{12}$ or cyanocobalamin which is needed for our bodies to form haemoglobin and deficiencies cause pernicious anaemia. Cobalt is also used as an enzyme activator, e.g. in carbonic anhydrase or carboxypeptidiase[1]. Acute toxicity of cobalt results diarrhoea, loss of appetite, paralysis of the hind legs and lowering of body temperature prior to death [2]. It is also reported to be carcinogenic in both plants [3] and animals [4]. The effective toxicity, genotoxocity and micronutrient activity of cobalt are dose dependant which need to be accurately determined with much confidence to properly assess areas of health risk, otherwise prognosis and diagnosis of disease will be erratic that may culminate into wrong treatment and fatal end. Therefore, its trace and ultra trace analysis is of paramount importance. Very few works on fluorimetric determination of cobalt (II) have been reported in the literature. Review on previous works reveals that these are low sensitive, unselective and encountered with high interferences [5-13]. Another quenchofluorimetric method for Co (II) determination was reported from this laboratory by Pal and Banerjee [14] using bathophenanthroline in 50\% ethanolic medium. The insolubility of the reagent in water is one of the drawbacks and further applications to alloys and ores are yet to be done. The present method is simple, virtually selective, and sensitive and has successfully applied to complex matrices.

\subsection{Instrumentation}

\section{Experimental}

All fluorescence measurements were performed on a Shimadzu Spectrofluorophotometer (RF 5000) equipped with a $150 \mathrm{~W}$ Xenon lamp, 12 inch colour video display, parallel line thermo sensitive printer recorder, $1 \mathrm{x} 1 \mathrm{~cm}$ quartz cells and a Shimadzu ASC-5 auto sample changer. A digital pH meter (Model pH 5651; Electronic Corporation of India) was used to measure pH. A Hanovia fluorescence lamp (Model 11A; Hanovia Limited, England) was employed for visual study of fluorescence intensity changes qualitatively.

\subsection{Reagents}

\subsubsection{Cobalt (II) standard solution}

A standard stock solution of Co (II) $(1 \mathrm{ng} / \mathrm{ml})$ was prepared by dissolving $0.4769 \mathrm{~g}$. of $\mathrm{CoSO}_{4} \cdot 7 \mathrm{H}_{2} \mathrm{O}(\mathrm{E}$. Merck, Pro-analysis) in $100 \mathrm{ml}$ volumetric flask with deionised water. Suitable aliquots from the stock solution were standardised by EDTA titration method using Xylenol orange as indicator [13].

\subsubsection{Bathophenanthrolinedisulphonate solution}

A $0.1 \%(\mathrm{~W} / \mathrm{V})$ corresponding to $1.693 \times 10^{-3} \mathrm{M}$ bathophenanthrolinedisulphonate (Liba - Chemie Wein - Fischamend) solution was prepared in deionised water. This solution was stable for more than a month if preserved in refrigerator. From this stock solution, more diluted solutions were prepared as and when needed. 


\subsubsection{Buffer solution}

A $100 \mathrm{ml}$ acetate buffer solution ( $\mathrm{pH} 4.27$ ) was prepared by mixing $70 \mathrm{ml}$ of $0.2 \mathrm{M}$ acetic acid and $30 \mathrm{ml}$ of $0.2 \mathrm{M}$ sodium acetate solutions.

\subsubsection{Other solutions}

A large number of solutions of inorganic ions and complexing agents were prepared from their Analar grade or equivalent grade water soluble salts. In case of insoluble salts, special dissolution methods were adopted [15]. Doubly distilled demineralised water was used throughout the study.

\subsection{Procedure}

To $1 \mathrm{ml}$ sample solution containing $0.02-0.2 \mu \mathrm{g}$ or $0.2-2.0 \mu \mathrm{g}$ or $2.0-10 \mu \mathrm{g}$ of cobalt (II) in a $10 \mathrm{ml}$ volumetric flask, were respectively added $0.1 \mathrm{ml}$ of $10^{-4} \mathrm{M}$ or $0.3 \mathrm{ml}$ of $10^{-4} \mathrm{M}$ or $1 \mathrm{ml}$ of $10^{-3} \mathrm{M}$ bathophenanthrolinedisulphonate solution and $2 \mathrm{ml}$ of acetate buffer $(\mathrm{pH} 4.27)$. The volume was then made up to the mark with deionised water. Fluorescence intensity of the complex was then measured against a corresponding reagent blank at $444.8 \mathrm{~nm}$, keeping the excitation wavelength maximum at $288 \mathrm{~nm}$. The concentration of cobalt (II) in the unknown sample was determined with the help of a concurrently prepared calibration graph from standard cobalt (II) solution.

\subsection{Spectral characteristics}

\section{Results And Discussion}

The uncorrected excitation and emission spectra of the bathophenanthrolinedisulphonate solution are shown in Fig.1. The wavelength maxima of excitation and emission were found to occur at $288 \mathrm{~nm}$ and $444.8 \mathrm{~nm}$, respectively.

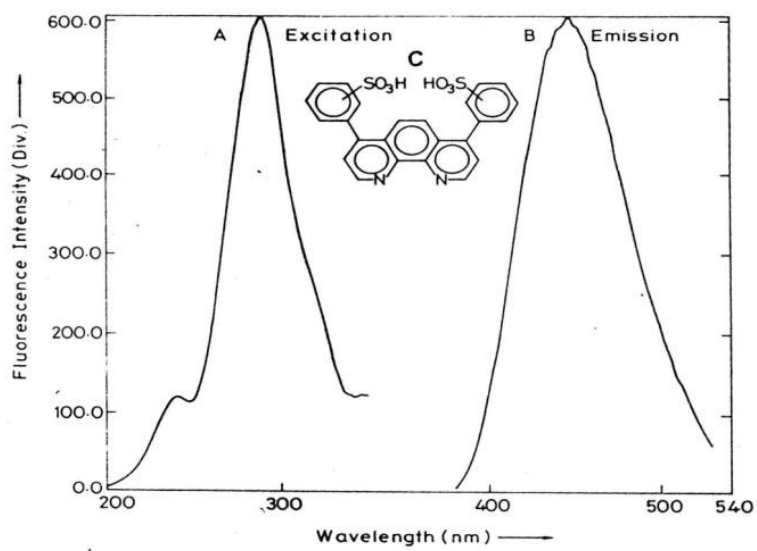

Fig.1. Excitation (A) and emission (B) spectra of Bathophenanthrolinedisulphonate (4, 7-diphenyl -1, 10phenanthrolinedisulphonate), (C) Structure of Bathophenanthrolinedisulphonate.

\subsection{Effect of time}

The extent of fluorescence quenching intensity remained constant from 5 min of volume make-up to 24hrs. Longer than this time was not studied. Fig.2 shows effect of time.

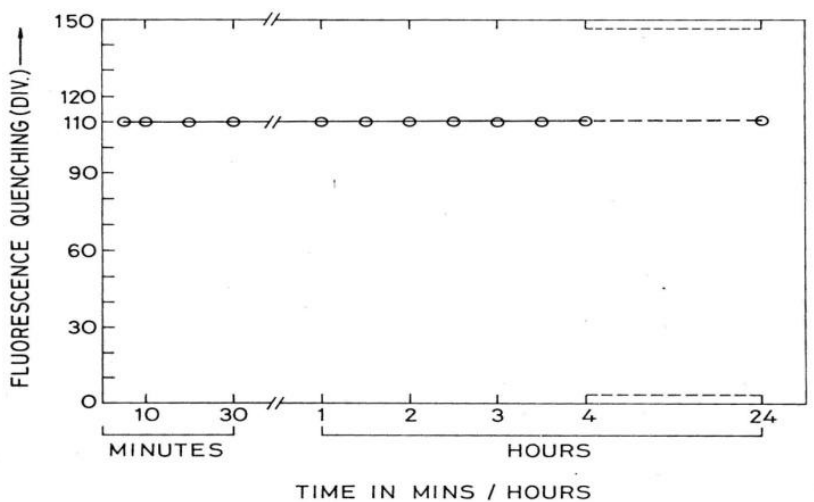

Fig.2. Effect of time on the fluorescence quenching intensity of $\mathrm{Co}(\mathrm{II})$ - Bathophenanthrolinedisulphonate system. 


\subsection{Effect of $\mathrm{pH}$}

The study of the effect of $\mathrm{pH}$ while other conditions in the procedure remained the same showed that the maximum and constant fluorescence quenching intensity occurred in the $\mathrm{pH}$ range $4.0-4.7$. Fig.3 shows effect of $\mathrm{pH}$.

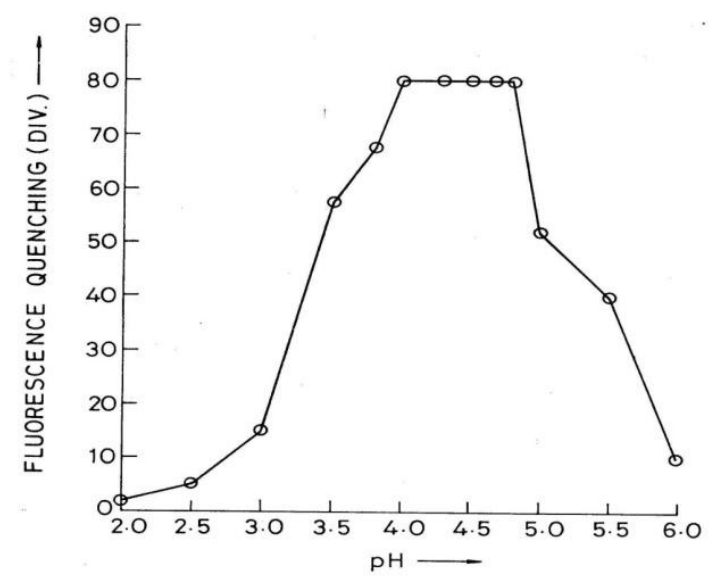

Fig.3. Effect of $\mathrm{pH}$ on the fluorescence quenching intensity of $\mathrm{Co}(\mathrm{II})$ - Bathophenanthrolinedisulphonate system.

\subsection{Effect of buffer solution}

Study of the effect of buffer solution showed that the presence of $1-5 \mathrm{ml}$ sodium acetate - acetic acid buffer of $\mathrm{pH} 4.27$ added to the total $10 \mathrm{ml}$ volume of metal - reagent system had no effect on the fluorescence quenching intensity. Consequently, $2 \mathrm{ml}$ of this buffer was used throughout the study.

\subsection{Effect of metal concentration (calibration graph)}

The fluorescence intensity versus cobalt (II) concentration calibration graph was rectilinear for a total range of $0.001-1.0 \mathrm{ppm}$ cobalt (II). For convenience of measurements, it was distributed into 3 sets; $1.0-10.0$ ppb, $10.0-200.0 \mathrm{ppb}$ and $0.2-1.0 \mathrm{ppm}$ of Co (II). Typical calibration graphs as displayed in the video screen of the Spectrofluorophotometer are reproduced in Fig.4.

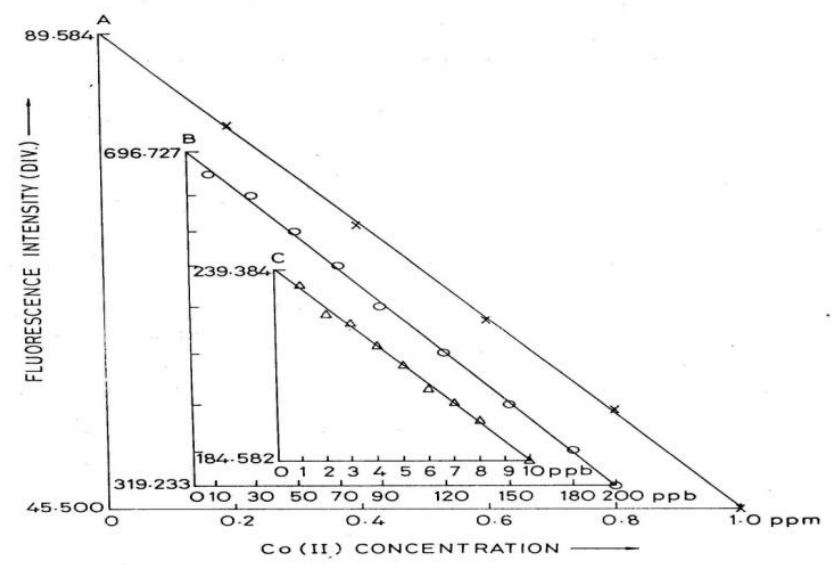

Fig.4. Calibration graphs; (A) $0.2-1.0$ ppm, Co(II); (B) $10.0-200.0$ ppb, Co(II); (C) $1.0-10.0$ ppb, Co (II).

\subsection{Effect of foreign ions}

The individual effects of over 60 anions, cations and some common complexing agents on the determination of 50ppb Co (II) were studied separately by the procedure described earlier. Less than 3\% error by (W/W) ratio of foreign ion to Co (II) added was the criterion of non-interference. 1000 - fold excess of $\mathrm{Li}(\mathrm{I})$, $\mathrm{Na}(\mathrm{I}), \mathrm{K}(\mathrm{I}), \mathrm{Ba}(\mathrm{II}), \mathrm{Ca}(\mathrm{II}), \mathrm{Sr}(\mathrm{II}), \mathrm{Mg}(\mathrm{II}), \mathrm{Ag}(\mathrm{I}), \mathrm{As}(\mathrm{III}), \mathrm{La}(\mathrm{III}), \mathrm{Th}(\mathrm{IV}), \mathrm{U}(\mathrm{VI}), \mathrm{Cl}^{-}, \mathrm{I}^{-}, \mathrm{Br}^{-}, \mathrm{NO}_{3}^{-}, \mathrm{HSO}_{4}^{-}, \mathrm{HSO}_{3}{ }^{-}$, $\mathrm{HPO}_{4}^{2-}, \mathrm{SO}_{3}^{2-}, \mathrm{SO}_{4}^{2-}, \mathrm{PO}_{4}^{3-}, \mathrm{ClO}_{4}^{-}, \mathrm{SCN}, \mathrm{S}_{2} \mathrm{O}_{3}^{2-}, \mathrm{H}_{2} \mathrm{O}_{2}, \mathrm{H}_{2} \mathrm{C}_{4} \mathrm{H}_{4} \mathrm{O}_{6}$ (tartaric acid), $\mathrm{SC}\left(\mathrm{NH}_{2}\right)_{2}$ (thiourea) and $\mathrm{CH}_{3} \mathrm{COO}^{-}$, EDTA do not interfere. This is not the maximum tolerance limit of these foreign ions but the actual amounts studied. The maximum tolerance limits of the following ions are; 500 - fold excess: $\mathrm{H}_{3} \mathrm{C}_{6} \mathrm{H}_{5} \mathrm{O}_{7}$ (citric acid), $\mathrm{Sn}$ (II), $\mathrm{Sn}$ (IV), F-; 100 - fold excess: $\mathrm{H}_{2} \mathrm{C}_{6} \mathrm{O}_{4}$ (oxalic acid), $\mathrm{C}_{6} \mathrm{H}_{8} \mathrm{O}_{6}$ (ascorbic acid), $\mathrm{Pb}$ (II), $\mathrm{Al}(\mathrm{III}), \mathrm{Tl}(\mathrm{III})$; 50 - fold excess: $\mathrm{Zn}(\mathrm{II}), \mathrm{Mn}(\mathrm{II}), \mathrm{Se}(\mathrm{IV}), \mathrm{Bi}(\mathrm{III})$ (in presence of thiourea); 10 - fold excess: $\mathrm{Cd}(\mathrm{II}), \mathrm{Cr}(\mathrm{III})$, 
$\mathrm{Sb}(\mathrm{III}), \mathrm{Fe}(\mathrm{III}), \mathrm{Sb}(\mathrm{III}), \mathrm{Cr}(\mathrm{VI}), \mathrm{Zr}(\mathrm{VI}), \mathrm{Hg}(\mathrm{II})$ (in presence of thiosulphate), $\mathrm{V}(\mathrm{V})$ (in presence of tartarate), $\mathrm{W}(\mathrm{VI})$ (in presence of $\mathrm{F}^{-}$), $\mathrm{Mo}(\mathrm{VI})$ (in presence of citrate). $\mathrm{Cu}(\mathrm{II}), \mathrm{Ni}(\mathrm{II})$ and $\mathrm{Fe}(\mathrm{II})$ interfere in the determination procedure. However, these inferences could be removed by a quick ion - exchange separation process using Amberlite IRA - 400 (Chloride form)[15].

\subsection{Separation of Interfering Ions on Anion Exchanger ion exchanger [15]}

About 2 g. of anion exchange resin, Amberlite IRA - 400 (Chloride form) was taken in a beaker and repeatedly washed with deionised water to remove the fine particles. The resin was then transferred in a ion exchange column of specific i.d. $(1 \mathrm{~cm})$ containing a plug of glass wool until a column of well-packed resin about $5 \mathrm{~cm}$ long was obtained. The resin in the column was washed twice with deionised water. $20 \mathrm{ml}$ of $9 \mathrm{M}$ $\mathrm{HCl}$ was then passed through the column and drained to almost bed level. A solution containing known amount of $\mathrm{Co}$ (II) and interfering ions was mixed with conc. $\mathrm{HCl}(11.3 \mathrm{M})$ so that the final morality of the solution was $9 \mathrm{M}$. It was then passed through the resin at the rate of $2 \mathrm{ml} / \mathrm{min}$. Another $20 \mathrm{ml}$ of $9 \mathrm{M} \mathrm{HCl}$ was again passed in order to elute the interfering ions completely. Co (II) was finally eluted with $50 \mathrm{ml}$ of deionised water at the rate of $3 \mathrm{ml} / \mathrm{min}$. The effluent was collected a beaker and concentrated to a small volume inside fume cupboard in order to remove the excess of acid. After cooling, it was neutralised with dil.NaOH solution and finally diluted to $50 \mathrm{ml}$ with deionised water. From suitable aliquots, cobalt content was then fluorimetrically determined as described earlier with the help of concurrently prepared calibration graph from standard Co(II) solution, also absorbed in the similarly conditioned resin bed and eluted identically.

\section{Applications}

The proposed method was successfully applied to the determination of Cobalt (II) in a series of synthetic mixtures of various compositions, certified reference materials and environmental water samples. The results of analyses were in excellent agreement with their certified values. In case of environmental water samples of unknown composition, the analyses were done in both Cobalt (II) - spiked and - unspiked conditions. These results were in agreement with those reported by AAS method. These results are shown in Table 1,2 and 3.

TABLE 1. Determination of Cobalt (II) in Synthetic Mixtures.

\begin{tabular}{|c|c|c|c|}
\hline Composition of the mixture $^{a}$ & $\begin{array}{c}\text { Co (II) present } \\
(\%)\end{array}$ & $\begin{array}{l}\text { Co (II) found } \\
(\%)\end{array}$ & $\begin{array}{c}\text { Recovery } \\
(\%)\end{array}$ \\
\hline A. $\quad \mathrm{Fe}^{3+}(2), \mathrm{Cu}^{2+}(1), \mathrm{Ni}^{2+}(1), \mathrm{Co}^{2+}(0.1)$. & 2.43 & $2.68^{\mathrm{c}} \pm 0.0008$ & 110 \\
\hline $\begin{array}{ll}\text { B. } & \mathrm{Mg}^{2+}(50), \mathrm{Pb}^{2+}(1), \mathrm{As}^{3+}(10), \mathrm{Th}^{4+}(50), \mathrm{La}^{3+}(50), \\
& \mathrm{Co}^{2+}(0.1) .\end{array}$ & 0.062 & $0.064 \pm 0.0007$ & 103 \\
\hline $\begin{array}{ll}\text { C. } & \text { As in B, Citrate }(50), \mathrm{Mo}^{6+}, \mathrm{Bi}^{3+}(1), \\
\text { Thio-urea }(100) .\end{array}$ & 0.031 & $0.032 \pm 0.0020$ & 103 \\
\hline D. $\quad$ As in $\mathrm{C}, \mathrm{Cd}^{2+}(1), \mathrm{S}_{2} \mathrm{O}_{3}{ }^{2-}(100), \mathrm{Hg}^{2+}(1)$. & 0.024 & $0.026 \pm 0.0010$ & 108 \\
\hline $\begin{array}{ll}\text { E. } & \text { As in D, Tartarate (100), } \mathrm{Zn}^{2+}(5), \\
& \mathrm{Fe}^{3+}(1) .\end{array}$ & 0.019 & $0.019 \pm 0.0010$ & 108 \\
\hline $\begin{array}{ll}\text { F. } & \text { As in } \mathrm{E}, \mathrm{Cr}^{6+}(1), \mathrm{Al}^{3+}(100), \mathrm{Zr}^{6+}(10), \\
& \mathrm{Mn}^{2+}(2) .\end{array}$ & 0.015 & $0.015 \pm 0.0007$ & 100 \\
\hline
\end{tabular}

column.

$\mathrm{a}-$ Composition in ppm. $\mathrm{b}-$ Mean + Standard Deviation $(\mathrm{n}=5) . \mathrm{c}-$ Using ion-exchange

TABLE 2. Determination of Cobalt (II) in Certified Reference Materials (CRM).

\begin{tabular}{|l|c|c|c|}
\hline \multicolumn{1}{|c|}{$\begin{array}{c}\text { Composition of CRM } \\
(\boldsymbol{\%})\end{array}$} & $\begin{array}{c}\text { Co }(\mathbf{I I}) \text { spiked } \\
(\mathbf{n g} / \mathbf{m l})\end{array}$ & $\begin{array}{c}\text { Co }(\mathbf{I I}) \text { found } \\
(\mathbf{n g} / \mathbf{m l})\end{array}$ & $\begin{array}{c}\text { Recovery } \\
(\%)\end{array}$ \\
\hline $\mathrm{BAS}(20 \mathrm{~b}) \mathrm{Al}-$ alloy & 0.00 & $0.00 \pm 0.063$ & 100.0 \\
$\mathrm{Cu}=4.1, \mathrm{Fe}=0.43, \mathrm{Mn}=0.19, \mathrm{Mg}=1.61$, & 20.0 & $20.7 \pm 0.418$ & 103.5 \\
$\mathrm{Si}=0.24, \mathrm{Al}=90.50, \mathrm{Ni}=1.93$ & 40.0 & $40.5 \pm 0.360$ & 101.2 \\
& & & \\
\hline $\mathrm{BAS}(32 \mathrm{a}) \mathrm{Al}-\mathrm{Bronze}$ & 0.00 & $0.00 \pm 0.0085$ & 100.0 \\
$\mathrm{Al}=8.8, \mathrm{Cu}=85.9, \mathrm{Mn}=0.27, \mathrm{Ni}=1.16$, & 20.0 & $21.1 \pm 0.519$ & 105.5 \\
$\mathrm{Zn}=0.94, \mathrm{Fe}=2.69$ & 40.0 & $40.7 \pm 0.396$ & 101.7 \\
\hline
\end{tabular}

$\mathrm{a}-$ Mean \pm Standard Deviation $(\mathrm{n}=5)$ 
TABLE 3. Determination of Cobalt (II) in Environmental Water Samples.

\begin{tabular}{|c|c|c|c|c|}
\hline \multirow[t]{2}{*}{ Sample } & \multirow[t]{2}{*}{$\begin{array}{c}\text { Composition by AAS } \\
(\mu \mathrm{g} / \mathrm{ml})\end{array}$} & \multicolumn{2}{|c|}{$\begin{array}{c}\text { Amount of Co (II) } \\
(\mu \mathrm{g} / \mathrm{ml})\end{array}$} & \multirow[t]{2}{*}{$\begin{array}{c}\text { Recovery } \\
(\%)\end{array}$} \\
\hline & & Added & Found $^{\mathrm{a}}$ & \\
\hline Tap water & --- & $\begin{array}{l}0.00 \\
0.02 \\
0.05\end{array}$ & $\begin{array}{c}0.00 \\
0.02 \pm 0.0017 \\
0.052 \pm 0.002\end{array}$ & $\begin{array}{l}100 \\
100 \\
104\end{array}$ \\
\hline $\begin{array}{l}\text { Deep tube } \\
\text { well water }\end{array}$ & --- & $\begin{array}{l}0.00 \\
0.02 \\
0.05\end{array}$ & $\begin{array}{c}0.00 \\
0.02 \pm 0.001 \\
0.053 \pm 0.002\end{array}$ & $\begin{array}{l}100 \\
100 \\
106\end{array}$ \\
\hline $\begin{array}{l}\text { Factory drain } \\
\text { Waters } \\
\text { A. }\end{array}$ & $\begin{array}{l}\mathrm{As}^{3+}<0.01, \mathrm{Hg}^{2+}<0.01, \mathrm{~Pb}^{2+}<0.01 \\
\mathrm{Cr}^{3+}=0.09, \mathrm{Ni}^{2+}=0.20, \mathrm{Ag}^{+}=0.02 \\
\mathrm{Zn}^{2+}=0.19, \mathrm{Na}^{+}=56, \mathrm{Cu}^{2+}=0.03 \\
\mathrm{Cl}^{-}=108, \mathrm{SO}_{4}{ }^{2-}=25\end{array}$ & $\begin{array}{l}0.00 \\
0.02 \\
0.05\end{array}$ & $\begin{array}{l}0.023 \pm 0.0017 \\
0.043 \pm 0.0021 \\
0.072 \pm 0.0022\end{array}$ & $\begin{array}{c}100 \\
98\end{array}$ \\
\hline B. & $\begin{array}{l}\mathrm{As}^{3+}=0.01, \mathrm{Hg}^{2+}=0.01, \mathrm{~Pb}^{2+}=0.01 \\
\mathrm{Cr}^{3+}=0.04, \mathrm{Ni}^{2+}=0.18, \mathrm{Ag}^{+}=0.008 \\
\mathrm{Zn}^{2+}=0.19, \mathrm{Na}^{+}=52, \mathrm{Cu}^{2+}=0.02 \\
\mathrm{Cl}^{-}=105, \mathrm{SO}_{4}{ }^{2-}=23\end{array}$ & $\begin{array}{l}0.00 \\
0.02 \\
0.05\end{array}$ & $\begin{array}{l}0.017 \pm 0.001 \\
0.04 \pm 0.001 \\
0.068 \pm 0.001\end{array}$ & $\begin{array}{l}115 \\
102\end{array}$ \\
\hline C. & $\begin{array}{l}\mathrm{As}^{3+}=0.01, \mathrm{Hg}^{2+}=0.01, \mathrm{~Pb}^{2+}=0.01 \\
\mathrm{Cr}^{3+}=0.04, \mathrm{Ni}^{2+}=0.15, \mathrm{Ag}^{+}=0.005 \\
\mathrm{Zn}^{2+}=0.32, \mathrm{Na}^{+}=54, \mathrm{Cu}^{2+}=0.01 \\
\mathrm{Cl}^{-}=108, \mathrm{SO}_{4}{ }^{2-}=24\end{array}$ & $\begin{array}{l}0.00 \\
0.02 \\
0.05\end{array}$ & $\begin{array}{l}0.011 \pm 0.002 \\
0.032 \pm 0.002 \\
0.063 \pm 0.002\end{array}$ & $\begin{array}{l}105 \\
104\end{array}$ \\
\hline D. & $\begin{array}{l}\mathrm{As}^{3+}=0.01, \mathrm{Hg}^{2+}=0.01, \mathrm{~Pb}^{2+}=0.01 \\
\mathrm{Cr}^{3+}=0.004, \mathrm{Ni}^{2+}=0.1, \mathrm{Ag}^{+}=0.03 \\
\mathrm{Zn}^{2+}=0.12, \mathrm{Na}^{+}=53, \mathrm{Cu}^{2+}=0.01 \\
\mathrm{Cl}^{-}=105, \mathrm{SO}_{4}^{2-}=23\end{array}$ & $\begin{array}{l}0.00 \\
0.02 \\
0.05\end{array}$ & $\begin{array}{c}0.017 \pm 0.0017 \\
0.038 \pm 0.0026 \\
0.068 \pm 0.002\end{array}$ & $\begin{array}{l}105 \\
102\end{array}$ \\
\hline
\end{tabular}

$\mathrm{a}-$ Mean \pm Standard Deviation $(\mathrm{n}=5)$

\section{Conclusion}

The fairly solubility of the reagent, bathophenanthrolinedisulphonate, in water and non-requirement of any other solvents like alcohol are added advantages over previous methods. The method could be improved further if suitable complexing agents are available for masking the interfering ions instead of applying the ion-exchange process as suggested. Though the present method requires a quick ion-exchange separation process for removing interfering ions, it is far superior to others in terms of simplicity, sensitivity, wider determination range, prolong stability of fluorescence, non-requirement of any other solvent and applicability to complex matrices.

\section{Acknowledgement}

The author, Dr. K. Anand Singh gratefully acknowledges laboratory facilities providing by Analytical Chemistry Research Laboratory, Jadavpur University, and Kolkata for carrying out this work and also Manipur State Government for granting study leave.

\section{References}

[1]. David R. Williams, The Metals of Life, Van Nostrand Reinhold Company, London, 1971.

[2]. Stokinger, H.E., The Metals, in Patty's Industrial Hygiene and Toxicology, Clayton, G.D. and Clayton, F.E. (Eds), John Wiley and Sons, New York, 1981, p. 1605.

[3]. Herich, R., Chromosoma, 17 (1965), 194.

[4]. Miyaki, R., Akamatsu, N., Ono, T and Koyama, H., H. Motat. Res, 68 (1979) 259.

[5]. Zamochnick, S.B. and Rechnitz, G.A. Z. Anal. Chim., 199 (6) (1964), 424 - 429 (Eng); Anal. Abstr., 12 (1965), 688.

[6]. Possidoni de Albinati, J.F., An Asoc. Quim.Argent, 55(1 - 2) (1967) 61; Anal. Abstr. 15(1968), 3934.289.

[7]. Schenk, G.H., Dilloway, K.P. and Coulter, J.S., Anal. Chem., 41 (1969) 510.

[8]. Kasa, I. and Bajnoczy, G., Period Polytech. Chem. Eng., 18 (4) (1974); Chem. Abstr., 89:21590w (1975).

[9]. Haddad, P.R., Alexander, P.W. and Smythe, L.E., Talanta, 23 (1978) 275.

[10]. Burns, D.T. and Hanprasopwattana, P., Anal. Chim. Acta, 115 (1980) 389 - 393.

[11]. Burns, D.T. and Hanprasopwattana, P., Anal. Chim. Acta, 134 (1982) 397.

[12]. Sanchez, F.G., Diaz, A.N. and Laserna, J.J., Anal. Chem.. 55 (1983) 253.

[13]. Quyang, Y., Cai, W., Chen. X. and Liu, G., Fenxi Shiyanshi, 8 (3) (1989)1 - 3 (Ch); Anal. Abstr., 52 (1990), 6 E 34.

[14]. Pal, B.K. and Banerjee, S.N., Ind.J. of Chem., 30 A (1991) 564.

[15]. Vogel, A.I., A Text Book of Qualitative Inorganic Analysis, $3^{\text {rd }}$ Ed., The English Language Book Society and Longman, London, 1969. 